\title{
Student Perceptions of and Learning in Makerspaces Embedded in their Undergraduate Engineering Preparation Programs
}

\section{Dr. Louis S. Nadelson, University of Central Arkansas}

Louis S. Nadelson has a BS from Colorado State University, a BA from the Evergreen State College, a MEd from Western Washington University, and a PhD in educational psychology from UNLV. His scholarly interests include all areas of STEM teaching and learning, inservice and preservice teacher professional development, program evaluation, multidisciplinary research, and conceptual change. Nadelson uses his over 20 years of high school and college math, science, computer science, and engineering teaching to frame his research on STEM teaching and learning. Nadelson brings a unique perspective of research, bridging experience with practice and theory to explore a range of interests in STEM teaching and learning.

\section{Dr. Idalis Villanueva, Utah State University}

Dr. Villanueva is an Assistant Professor in the Engineering Education Department and an Adjunct Professor in the Bioengineering Department in Utah State University. Her multiple roles as an engineer, engineering educator, engineering educational researcher, and professional development mentor for underrepresented populations has aided her in the design and integration of educational and physiological technologies to research 'best practices' for student professional development and training. In addition, she is developing methodologies around hidden curriculum, academic emotions and physiology, and engineering makerspaces.

\section{Dr. Jana Bouwma-Gearhart, Oregon State University}

Jana L. Bouwma-Gearhart is an associate professor of STEM education at Oregon State University. Her research widely concerns improving education at research universities. Her earlier research explored enhancements to faculty motivation to improve undergraduate education. Her more recent research concerns organizational change towards postsecondary STEM education improvement at research universities, including the interactions of levers (people, organizations, policy, initiatives) of change and documenting the good, hard work required across disciplinary boundaries to achieve meaningful change in STEM education.

\section{Ms. Estefany Soto, University of Central Arkansas}

Estefany Soto is pursuing a Ph.D. in Counseling Psychology at the University of Central Arkansas. She is working as a graduate research assistant with makerspace research and other STEM-related projects.

\section{Cindy Ann Lenhart, Oregon State University}

Cindy Lenhart is currently pursuing her Ph.D. in Education at Oregon State University. Her scholarly interest includes the intersection of postsecondary STEM faculty teaching and learning environments and organizational change. Cindy previously served as the Vice President for Community College Relations for Achieving the Dream, Inc., managing the Working Students Success Network, Engaging Adjunct Faculty, and other funded initiatives as well as leading Achieving the Dream's teaching and learning programs and network-engagement activities. Prior to joining Achieving the Dream, Cindy served for more than 20 years in community colleges as an associate vice president for instruction, a department chair, and a faculty member. Cindy holds a B.S and M.S in education and began her career as a middle and high school teacher.

\section{Kate Youmans, Utah State University}

Kate Youmans is a PhD candidate in the Department of Engineering Education at Utah State University. Kate earned her bachelor's degree in Mechanical Engineering from Worcester Polytechnic Institute and worked in the medical device industry designing surgical instruments before focusing on engineering outreach in MIT's Office of Engineering Outreach Programs. After receiving her master's degree in Science 
Education from Boston University, Kate helped open the American International School of Utah, a K-12 charter school in Salt Lake City. In her role as STEM Director Kate developed the schools programs in Computer Science, Robotics and Design Thinking.

\section{Yoon Ha Choi, Oregon State University}

Yoon Ha Choi is a PhD candidate in Science Education at Oregon State University. Yoon Ha holds a BA in Economics from the University of Chicago and an EdM from the Harvard Graduate School of Education. Yoon Ha's research interests include equity and diversity in STEM education, women of color in STEM, student experiences in higher education, and feminist narratives. 


\section{Student Perceptions of and Learning in Makerspaces Embedded in their Undergraduate Engineering Preparation Programs}

Building upon our two years of research on the use of makerspaces in undergraduate engineering programs, we engaged in a large-scale data collection from students enrolled in undergraduate engineering preparation programs with affiliated makerspaces established for a minimum of three years. Using web searches, and other sources of information (e.g. references from other researchers or faculty members), we have identified 28 institutions that met our criteria. Working with a third party, we gathered over 574 responses from undergraduate engineering students with makerspace experiences spread across the 28 institutions. To gather our data, we created and validated an online survey with a combination of quantitative and qualitative items. We constructed a survey with subscales aligned with motivation to learn, growth mindset, learning goal orientation, knowledge of engineering as a profession, and belongingness and inclusion, as associated with work within makerspaces. We found significant positive correlations among the variables, positive levels of motivation, growth mindset, knowledge of engineering as a profession, and belongingness. We found differences in levels for gender, engineering majors, and student class standing. We discuss the implications for our findings in the context of undergraduate engineering student learning in makerspaces.

\section{Introduction}

Makerspaces, a location with tools (electronic and hand) for rapid prototyping, have become more widely used in undergraduate engineering preparation programs [1]. There is a general expectation that students using the makerspaces will gain deeper knowledge of engineering and therefore, will be better prepared as engineering professionals [2]. Yet, there is limited research about what students are learning about engineering in the spaces, and the influence of interactions in the spaces on their interest and pursuit of engineering as a profession. We have attempted to address the gap in the literature by gathering data from over 500 undergraduate engineering students from 28 universities across the United States with makerspaces integrated into their engineering preparation programs. Given the interest and investment in makerspaces, there is warrant for learning more about what students are learning in the spaces.

\section{Makerspaces}

Makerspaces can have many different forms, uses, be available for different users, and configured in many different ways [3]. The general notion of makerspaces is to equip individuals with hand tools, smaller and larger power tools, and rapid prototyping tools (e.g. 3D printers, laser cutters, sewing machines, and circuit board etchers), so that the users of the spaces have the tools they need to develop models, prototypes, modifications, or one-of-a-kind products [4], [5], [6], [7]. Makerspaces can be community-based or situated within specific institutions and access to the spaces can range from open to the public to highly restrictive [3].

Of interest to us are maker spaces that are situated or integrated with colleges of engineering and used by engineering students - particularly to complete assignments that require the use of the space to create some sort of product. There is a range of configurations and foci for makerspaces on college campuses, ranging from open access for all students in a central location, such as a 
library, to college or program specific spaces with access limited to specific students for specific projects [3]. Some university makerspaces are student led, with the students managing and monitoring the space with little or no input from faculty members or administrators [3]. At other universities, the makerspaces have part or full time funded positions such as space director, lab managers, and student workers, who work together to support student engagement in the spaces. Regardless of the configuration and leadership of the spaces, the goal is to create environments for students to be able to produce products related to their course assignments.

\section{Learning in Makerspaces}

The primary goal of makerspaces in engineering programs is to increase student knowledge of engineering [8], [7], [9]. The general premise is, if undergraduate engineering students engage in makerspaces to complete assignments, they will learn more about the processes of engineering and design [10], [7]. However, we maintain that when undergraduate engineering students are expected to work in makerspaces they are likely learning more than just engineering. We speculate that students are further developing a sense of belongingness and inclusion in the profession, developing their professional identity as an engineer, increasing their motivation to learn and persist when faced with failure or challenges, and they further develop an engineering mindset. Consistent with the most recent Accreditation Board for Engineering and Technology (ABET) [11], makerspaces may increase the ability to meet the expected student outcomes for engineering preparation programs [8]. Thus, makerspaces can be used to increase students' ability to apply STEM knowledge, conduct experiments, analyze the outcomes of those experiments, work within constraints, work in teams, understand engineering as service to society, and understand their professional and ethical responsibilities. It is important to keep in mind many engineers working in large companies may never directly create a prototype as they might in a makerspace, yet, their experience in makerspaces is likely to increase their knowledge of what is possible when creating prototypes [12]. Thus, through the work in makerspaces, students are likely to learn more about the process of moving from idea, to design, to developing a working model, which likely involves multiple iterations [13] and thereby, they increase their knowledge of the process and knowledge needed to be a professional engineer. Therefore, there is justification for researching the engineering knowledge students gain from their makerspace experiences.

\section{Knowledge of Engineering as a Profession}

The knowledge of engineering we focused on in our research aligns with the perception of engineering as service to society [11]. Engineering from a $21^{\text {st }}$ century perspective, focuses on finding solutions aligned with the needs and expectations of clients, while adhering to ethical and societal expectations of making the world a better place for others to live in [14]. There is evidence that the structure of some engineering programs may not be conducive to developing a mindset aligned with $21^{\text {st }}$ century engineering [15]. Given the potential for makerspace projects to be aligned with a $21^{\text {st }}$ century philosophy of engineering, there is justification for assessing if students are developing a $21^{\text {st }}$ century engineering mindset.

\section{Belongingness and Inclusion}


Through the use of makerspaces, students may gain a sense of how much they perceive they belong and are included in situations reflective of engineering and the profession. Through makerspace activities and the perception of feeling included and developing a sense of belonging, students can determine if they are perceived as being part of the engineering community [12] and therefore, are or can be perceived as being professional engineers. We maintain that students who do not feel they belong or included in makerspaces may also feel they are not perceived to be future engineers, influencing their identity as being members of the profession and the community of engineers. Thus, gender, ethnicity, and culture may be associated with feeling of belonging in makerspaces, and an indicator of students' feeling of belonging in engineering and developing and engineering identity. Given students are likely to learn about their sense of belonging and inclusion in engineering as a profession in engineering preparation programs, there is warrant for examining the extent by which undergraduate engineering students feel like they belong and feel included in the context of makerspaces embedded in undergraduate engineering programs.

\section{Learning Goal Orientation}

Learning goal orientation emerged from achievement motivation theory [16], [17] and has been used to describe learning in two terms: valences of master content and performing well [18], [19]. Learning goal orientation is considered from the perspectives of approach and avoidance goals [20], [21]. When engaging using approach goals, students are driven to either master the knowledge they are being taught or perform well in comparison to others. From an avoidance perceptive, students avoid situations in which they may not be able to master content or are likely to under-perform. We hold the position that makerspaces are more likely to foster student development of mastery approach motivation to learn about engineering. Unlike other coursework that promote competition and expectations of performance, particularly in comparison to peers, makerspace activities require mastery of processes to complete projects within the spaces. Further, many makerspace assignments may have multiple solutions that may be very different but meet assignment goals. Thus, there is warrant for examining students' goal orientation with respect to their work in makerspaces.

\section{Motivation and Persistence}

Based on the premise of self-determination theory [22], one of the justifications for studentcentered hands-on/minds-on learning activities, is the potential to increase student motivation to learn [23], [24], as we have found to be true of makerspaces [12]. Makerspace activities are student-centered by design [25] with students designing and building prototypes based on criteria and constraints. Further, there is an expectation that if students are supported to be in control of their learning and learning activities, they are more likely to be motivated and therefore persist in their learning [26]. Thus, there is justification for examining undergraduate engineering students' motivation to learn and their persistence when working on projects and activities in makerspaces.

\section{Growth Mindset}


Growth mindset has been defined as, the extent to which learners keep an open mind to consider their ability to learn or perform [27], [28]. People who consider their current limitations predicts their limitations in the future (e.g., "I am bad at math"), hold a fixed mindset. In contrast, people who consider their current limitations can be overcome with effort or opportunity, hold a growth mindset. We posit that work in makerspaces increases the potential for students to develop a growth mindset due to the ability to experiment with solutions and engagement in multiple attempts with no real single and correct solution. In addition, the ability to modify and create new prototypes is relatively fast and easy with rapid prototyping machines. Thus, there is justification for assessing engineering students' perceptions of growth mindset in the context of their work in makerspaces.

\section{Method}

\section{Research Questions}

To frame our research on undergraduate engineering students' perceptions, engagement, and learning in makerspaces associated with their coursework, we developed the following guiding research questions:

- What are students learning about engineering as a profession in their work in makerspaces?

- What is the learning goal orientation and growth mindset of students working in makerspaces?

- How are makerspaces associated with student motivation to learn?

- What are students' perceptions of belonging and being included in makerspaces?

- How are students' personal characteristics associated with their perceptions, engagement and learning in makerspaces?

\section{Participants}

The participants in our research were undergraduate engineering students. These students were drawn from 28 universities that we identified have had makerspaces embedded into their undergraduate engineering programs for at least 3 years. We had 574 undergraduate engineering students participate in our research and complete our survey. Of the 574 students that completed our survey, approximately $13.5 \%$ identified as freshman, $23 \%$ as sophomore, $27.5 \%$ as junior, $34.8 \%$ as senior, and $1 \%$ as other (e.g., $5^{\text {th }}$ year students). The students were on average 28.06 years old $(S D=8.50)$ and had completed an average of 3.98 years of college $(S D=1.76)$. Approximately $58 \%$ of the participants identified as male, $41.5 \%$ identified as female, and .5\% identified as other or declined to share their gender. The largest percentage of identified academic majors was mechanical engineering (35\%), closely followed by computer engineering $(33.7 \%)$, and then civil engineering (11.7\%), electrical engineering (10.8\%), and other (e.g. aerospace engineering, mechatronics, biomedical engineering- 5.4\%). The amount of time that the students self-reported that they spent per week working on personal and course projects in makerspaces is presented in Table 1.

Table 1. Percent of Responses to Time Spent working on Personal and Professional Projects in Makerspaces 


\begin{tabular}{ccc}
\hline Time & $\begin{array}{c}\text { Personal Projects } \\
\text { (Percent) }\end{array}$ & $\begin{array}{c}\text { Course/Class projects } \\
\text { (Percent) }\end{array}$ \\
\hline 0-3 hours & $18.3 \%$ & $13.4 \%$ \\
4-6 hours & $27.7 \%$ & $34.3 \%$ \\
7-9 hours & $32.2 \%$ & $28.5 \%$ \\
10-12 hours & $15.5 \%$ & $16.3 \%$ \\
13+ hours & $6.3 \%$ & $7.3 \%$ \\
\hline
\end{tabular}

\section{Survey}

We used a revised version of our student engagement in makerspaces survey [1]. Based on the factor analysis and input from the research team members, we increased the clarity of the item stems, modified the stems to be more concise, and modified the stems to reduce construct alignment overlap for any single item. The revised version of the survey had 33 selected response items that students answered on a standard Likert scale. We used the traditional Likert scale with 1 representing "Strongly Disagree" 2 representing "Disagree", 3 representing "Neutral", 4 representing "Agree" and 5 representing "Strongly Agree."

Our final survey contained subscales for motivation to learn, growth mindset, learning goal orientation, knowledge of engineering as a profession, and belongingness, and a series of demographic items. The item stems included statements such as, "I prefer to work on makerspace projects that have no clear answer" and "I feel like I can really trust fellow students in the makerspace" and some negative phrased items such as, "I feel disconnected to fellow students in the makerspace" and "Working on engineering projects in the makerspace with no quick solutions is a waste of time." The survey also included demographic items and items focused on student perceptions of engineering as a career such as, "Please rate your knowledge of the engineering profession" and "What is the primary reason you want to become an engineer?" The survey had a Cronbach's alpha of .84 indicating an acceptable level of reliability.

\section{Data Collection}

We worked with Qualtrics to gather full responses from at least 500 participants who met our criteria of being an undergraduate engineering major at any of the 28 institutions of which we identified as having a makerspace embedded into their undergraduate engineering preparation program for at least three years. We structured our survey so that when any participant responded with "yes" to being an engineering major, they were able to progress to the next question which asked if they had experience in makerspaces as part of their undergraduate engineering program. If they answered "yes" to the makerspace item, they were able to complete the remainder of the survey. Qualtrics attracted 3919 students to the survey, but only 575 students met our criteria for participation and fully completed our survey. Data collection took place over a period of about three weeks.

\section{Data Analysis}


Following data collection, we downloaded the data into Excel to remove the responses from any participant who had not completed at least $90 \%$ of the survey items. We then imported the data into SPSS for further conditioning, including replacing missing values with the series mean and reverse coding the responses to any items that were negatively stated. Once our data set was complete, we calculated the composite scores for our subscale measures of growth mindset, goal orientation, knowledge of engineering as a profession, motivation, and belongingness. We calculated the subscale composite scores by averaging the participant responses to the associated items. Once completed, we used a combination of responses to single items and composite scores for analysis.

\section{Results}

Our first research question asked: what are students learning about engineering as a profession in their work in makerspaces? To answer this question, we calculated the means and standard deviations for the responses to our items associated with knowledge of engineering (see Table 2). We found that work in the makerspace seems to increase students' understanding that engineering is about service to society, a perspective that is consistent with the philosophy of $21^{\text {st }}$ century engineering [15]. The students had high levels of agreement with understanding engineering is about helping others and problem solving, and lower levels of agreement to disagreement with the engineering profession being about tinkering, fixing things, and applying math and science. We interpret the results based on the Likert scale, thus, the means near 4.0 to be representative of agreeing to the statement and the means near 2.0 as representing disagreement with the statements.

Table 2. Knowledge of Engineering as a Profession

\begin{tabular}{lcc}
\hline \multicolumn{1}{c}{ Knowledge of Engineering as a Profession Item Stem } & Mean & SD \\
\hline $\begin{array}{l}\text { I enjoy how makerspaces provide opportunities for me to develop } \\
\text { skills and knowledge pertinent to engineering. }\end{array}$ & 4.09 & 0.98 \\
$\begin{array}{l}\text { Peer collaboration in the makerspace helps me develop my } \\
\text { problem solving skills. }\end{array}$ & 4.04 & 0.87 \\
$\begin{array}{l}\text { I prefer makerspace projects that result in solutions that help } \\
\text { others. }\end{array}$ & 4.03 & 0.93 \\
$\begin{array}{l}\text { I find ways to apply what I learn in the makerspace to what I learn } \\
\text { in my engineering courses. }\end{array}$ & 4.00 & 0.95 \\
$\begin{array}{l}\text { Makerspaces help me understand that engineering is about } \\
\text { inventing things. }\end{array}$ & 3.96 & 1.06 \\
$\begin{array}{l}\text { Makerspaces help me understand that engineering is about helping } \\
\text { society as a whole. }\end{array}$ & 3.94 & 1.06 \\
$\begin{array}{l}\text { Makerspaces help me understand that engineering is about } \\
\text { tinkering. }\end{array}$ & 2.22 & 1.14 \\
$\begin{array}{l}\text { Makerspaces help me understand that engineering is about fixing } \\
\text { things. }\end{array}$ & 2.09 & 1.06 \\
\hline
\end{tabular}


Makerspaces help me understand that engineering is about applying math and science concepts.

Our second research question asked: what is the learning goal orientation and growth mindset of students working in makerspaces? To answer this question, we examined the students' responses to our items aligned with their learning goals in makerspaces (see Table 3). We found that students' responses were in between neutral (Likert scale value of 3.0) and agree (Likert scale value of 4.0) to the items assessing their engagement in mastery approach learning in the makerspace activities. Interpreted, our results indicate that the students held neutral to moderate levels of masterly approach learning goal orientation. Thus, the students communicated perspectives that suggest they engage in makerspaces with the learning goal of mastering the concepts or processes that take place in the spaces.

Table 3. Student Learning Goal Orientation Associated with Their Work in Makerspaces

\begin{tabular}{lcc}
\hline Goal Orientation Item Stem & Mean & SD \\
\hline $\begin{array}{l}\text { It is important my makerspace projects are better than the projects } \\
\text { produced by others. }\end{array}$ & 3.78 & 1.05 \\
$\begin{array}{l}\text { I prefer to work on makerspace projects that have no clear answer. } \\
\text { Working on engineering projects in the makerspace with no quick }\end{array}$ & 3.37 & 1.07 \\
$\begin{array}{l}\text { solutions is a waste of time. } \\
\text { I avoid working on a makerspace projects where I might perform } \\
\text { poorly. }\end{array}$ & 3.07 & 1.26 \\
\hline
\end{tabular}

To assess the students' engagement in growth mindset practices in their makerspace activities, we examined the responses to the items associated with growth mindset work in makerspaces (see Table 4). The responses of the participants were neutral to agree about perspectives aligned with growth mindset in relations to their makerspace activities. Interpreted the results indicate that the students approach their projects and activities in the makerspaces from a growth mindset perspective and tend to disagree with fixed mindset preferences for work in the makerspaces.

Table 4. Student Growth Mindset Perspectives Associated with Their Work in Makerspaces

\begin{tabular}{lcc}
\hline \multicolumn{1}{c}{ Growth Mindset Item Stems } & Mean & SD \\
\hline $\begin{array}{l}\text { I feel confident in my ability to learn the material presented in the } \\
\text { makerspace. }\end{array}$ & 4.01 & 0.97 \\
$\begin{array}{l}\text { I'm embarrassed when I have to ask for advice or assistance when } \\
\text { working on a makerspace project. }\end{array}$ & 3.19 & 1.32 \\
$\begin{array}{l}\text { I get bored with makerspace projects that take a long time to } \\
\text { complete. }\end{array}$ & 3.05 & 1.32 \\
$\begin{array}{l}\text { I prefer makerspace projects that can be completed quickly. } \\
\text { P }\end{array}$ & 2.45 & 1.02 \\
\hline
\end{tabular}


Our third research question asked: how are makerspaces associated with student motivation to learn? To answer this question, we examined the items related to motivation to learn associated with their work in makerspaces (see Table 5). We found that students agreed to the related items, which we interpret as being reflective of moderate to high levels of motivation to learn when working in the makerspaces.

Table 5. Student Motivation to Learn in Makerspaces

\begin{tabular}{lrc}
\hline Motivation to Learning in Makerspace Item Stem & Mean & SD \\
\hline $\begin{array}{l}\text { I appreciate that makerspaces allow me to learn in a variety of ways. } \\
\text { I enjoy how makerspaces provide opportunities for me to develop skills } \\
\text { and knowledge pertinent to engineering. }\end{array}$ & 4.17 & 0.90 \\
$\begin{array}{l}\text { I feel able to meet the challenges of performing well on my makerspace } \\
\text { projects. }\end{array}$ & 4.07 & 0.98 \\
My goal in the makerspace is to complete the assigned project. & 2.01 & 0.94 \\
\hline
\end{tabular}

Our fourth research question asked: what are students' perceptions of belonging and being included in makerspaces? To answer this question, we examined the items associated with feelings of being included and respected in makerspaces (see Table 6). We found that students tended to agree they felt included and that they perceived they belonged in makerspaces (means were greater than the neutral value of 3.0). The one exception was not feeling respected by peers in the spaces, which was trending toward agree. The students also tended to disagree with the preferring to work alone in the spaces and feeling disconnected in the spaces. Overall, our data indicate that the students who work in makerspaces tend to feel like they belong in the spaces, but may also feel a lack of respect by their peers in the space.

Table 6. Feelings of Belonging in Makerspaces

\begin{tabular}{lcc}
\hline \multicolumn{1}{c}{ Belonging Item Stem } & Mean & SD \\
\hline I feel comfortable in makerspaces. & 4.13 & 0.90 \\
I feel like I can really trust the professor in the makerspace. & 4.12 & 0.92 \\
I feel comfortable in engineering classrooms. & 4.10 & 0.96 \\
I feel valued in makerspaces. & 4.04 & 0.86 \\
I feel valued in engineering classrooms. & 3.98 & 1.00 \\
I enjoy working on group projects in makerspaces. & 3.98 & 0.94 \\
I'd like a chance to interact with the professor in the makerspace more often. & 3.94 & 0.94 \\
I have made friends through my work in the makerspace. & 3.94 & 1.00 \\
I'd like a chance to interact with other students in the makerspace more often. & 3.91 & 0.93 \\
I feel like I can really trust fellow students in the makerspace. & 3.88 & 0.96 \\
I don't feel respected by my peers in the makerspace. & 3.53 & 1.31 \\
I prefer to work alone in the makerspace. & 2.76 & 1.16 \\
I feel disconnected to fellow students in the makerspace. & 2.70 & 1.31 \\
\hline
\end{tabular}


Our fifth research question asked: how are students' personal characteristics associated with their perceptions, engagement, and learning in makerspaces? To answer this question, we calculated the correlations among variables and ANOVAs using an array of personal characteristics as factors such as gender, engineering major, and undergraduate class standing. We found that all our subscales were significantly correlated at the $p<.01$ level, indicating as one subscale increased the others were likely to increase as well (See Table 7), although our calculations revealed that some of the relationships were stronger than others.

Table 7. Correlations among Composite Subscale Variables

\begin{tabular}{lcccc}
\hline & $\begin{array}{c}\text { Growth } \\
\text { Mindset }\end{array}$ & $\begin{array}{c}\text { Motivation } \\
\text { to Learn } \\
\text { of } \\
\text { Learning Goal }\end{array}$ & $\begin{array}{c}\text { Engineering } \\
\text { Profession }\end{array}$ & Belongingness \\
$\begin{array}{l}\text { Orientation } \\
\text { Growth Mindset }\end{array}$ & $.142^{* *}$ & $.191^{* *}$ & $.247^{* *}$ & $.172^{* *}$ \\
$\begin{array}{l}\text { Motivation to Learn } \\
\text { Knowledge of } \\
\text { Engineering Profession }\end{array}$ & $.317^{* *}$ & $.210^{* *}$ & $.346^{* *}$ \\
$* * \mathrm{p}<.01$ & & $.647^{* *}$ & $.691^{* *}$ \\
\end{tabular}

We continued our analysis by calculating the correlations among the survey subscales and the responses to items related to their perceived knowledge of engineering and makerspaces, importance of makerspaces to their education, and engagement in makerspaces for personal and educational purposes (see Table 8). With the exception of relationships between knowledge of makerspaces, time spent in makerspaces for both personal and class projects, and mastery learning goal orientation, we found all subscales to be correlated with the students' perceptions and engagement in engineering and makerspaces. The correlations indicate that students' knowledge and perceptions are aligned with their growth mindset, motivation, knowledge of engineering as a profession, and belongingness as associated with makerspaces.

Table 8. Correlations Among Subscales and Students' Perceptions and Engagement in Makerspaces

\begin{tabular}{lccccc}
\hline & $\begin{array}{c}\text { Knowledge of } \\
\text { Makerspaces }\end{array}$ & $\begin{array}{c}\text { Importance } \\
\text { of } \\
\text { Makerspaces }\end{array}$ & $\begin{array}{c}\text { Knowledge } \\
\text { of } \\
\text { Engineering }\end{array}$ & $\begin{array}{c}\text { Time spent in } \\
\text { makerspaces } \\
\text { for personal } \\
\text { projects }\end{array}$ & $\begin{array}{c}\text { Time spent in } \\
\text { makerspaces } \\
\text { for class } \\
\text { projects }\end{array}$ \\
\hline $\begin{array}{l}\text { Learning Goal } \\
\text { Orientation in } \\
\text { Makerspaces }\end{array}$ & .075 & $.131^{* *}$ & $.094^{*}$ & .014 & .022 \\
\hline
\end{tabular}




\begin{tabular}{|c|c|c|c|c|c|}
\hline $\begin{array}{l}\text { Growth Mindset } \\
\text { in Makerspaces }\end{array}$ & $.182^{* *}$ & $.093^{*}$ & $.198^{* *}$ & $.172^{* *}$ & $.137^{* *}$ \\
\hline $\begin{array}{l}\text { Motivation in } \\
\text { Makerspaces }\end{array}$ & $.323^{* *}$ & $.431^{* *}$ & $.413^{* *}$ & $.198^{* *}$ & $.222^{* * *}$ \\
\hline $\begin{array}{l}\text { Knowledge of } \\
\text { Engineering } \\
\text { Profession }\end{array}$ & $.271^{* * *}$ & $.408^{* * *}$ & $.361^{* * *}$ & $.216^{* * *}$ & $.235^{* * *}$ \\
\hline Belonging & $.360^{* *}$ & $.461^{* *}$ & $.405^{* *}$ & $.269^{* *}$ & $.257^{* *}$ \\
\hline $\begin{array}{l}\text { Knowledge of } \\
\text { Makerspaces }\end{array}$ & - & $.591^{* *}$ & $.616^{* *}$ & $.409^{* *}$ & $.331^{* *}$ \\
\hline $\begin{array}{l}\text { Importance of } \\
\text { Makerspaces }\end{array}$ & & - & $.536^{* *}$ & $.338^{* *}$ & $.271^{* *}$ \\
\hline $\begin{array}{l}\text { Knowledge of } \\
\text { Engineering }\end{array}$ & & & - & $.342^{* *}$ & $.249^{* *}$ \\
\hline $\begin{array}{l}\text { Time spent in } \\
\text { makerspaces for } \\
\text { personal projects }\end{array}$ & & & & - & $.561^{* *}$ \\
\hline
\end{tabular}

We concluded our analysis with calculating a series of comparisons using t-tests and ANOVAs. In our comparison of males and females along our subscales, we found differences in perceived growth mindset, $[t(567)=2.83, p<.01]$, with males $(n=331, M=3.40, S D=.80)$ significantly greater than females $(n=238, M=3.22, S D=.66)$, and differences for belongingness, $[t(567)=$ $2.27, p=.023$, with males $(n=331, M=3.82, S D=.52)$ significantly greater than females $(n=$ $238, M=3.71, S D=.55$ ). While significantly different, we do recognize the relatively small shifts in the means, and both males and females in the same relative region on the five-point scale. However, it is important to note we also found a difference for level of trust in other students $[t(567)=2.34, p=.02]$, with males $(n=331, M=3.97, S D=.92)$ significantly greater than females $(n=238, M=3.78, S D=.98)$. Thus, our research indicates females have less feelings of belongingness and trust of others in makerspaces. We found no difference for goal orientation, motivation to learn in makerspaces, and knowledge of engineering as a profession subscales.

In our continued exploration for differences by gender we found a significant difference for selfrated knowledge of makerspaces $[t(562)=4.82, p<.01]$, with males $(n=327, M=7.85, S D=$ $1.88)$ significantly greater than females $(n=237, M=7.00, S D=2.28)$ on a 10 point scale. We found a significant difference for self-rated importance of makerspaces to their education $[t(555)$ $=3.03, p<.01]$, with males $(n=323, M=7.99, S D=1.98)$ significantly greater than females $(n$ $=234, M=7.45, S D=2.24$ ) on a 10 point scale. We found a significant difference for self-rated knowledge of engineering as a profession $[t(562)=3.29, p<.01]$, with males $(n=327, M=$ $7.87, S D=1.88)$ significantly greater than females $(n=237, M=7.32, S D=1.99)$ also on a 10 
point scale. We also found a significant difference for hours spent in makerspaces for personal reasons $[t(567)=3.15, p<.01]$, with males $(n=331, M=2.76, S D=1.15)$ significantly greater than females $(n=238, M=2.46, S D=1.09)$. Interpreted males seem to have higher level of perceived knowledge of makerspaces and engineering as a profession, spend more item in maker spaces for personal reasons, and perceive higher levels of importance for makerspaces in their education. While the means for the different variables were within the same relative range on the scales, being significantly different is still worth noting.

We found differences by major for growth mindset $[F(5,567)=6.16, p<.01]$, with pairwise differences with mechanical engineering students indicating significantly lower growth mindsets than both civil and computer engineering students. Our analysis revealed differences by major for motivation $[F(5,567)=2.61, p=.024]$, with pairwise differences indicating civil engineering students indicated higher levels of motivation than electrical engineering students. We found differences by major for belongingness in makerspaces $[F(5,567)=6.16, p<.01]$, with the pairwise analysis indicating civil engineering students were significantly greater, indicating higher levels of belongingness, than electrical, biomedical, and mechanical engineering students.

Our analysis also revealed differences by academic level in knowledge of engineering as a profession $[F(4,568)=4.96, p<.01]$, with pairwise differences indicating seniors are significantly greater than freshman and sophomore level students, which indicates seniors have a higher level of knowledge of engineering as a profession in comparison to freshman and sophomore level students

\section{Discussion and Implications}

Through our research we have found that student engagement in makerspaces is likely to enhance their growth mindset, advance their learning goal orientation toward mastery achievement, knowledge of engineering as a profession, motivation to learn, and belongingness in engineering education. The potential for engagement in makerspaces to increase understanding and knowledge in engineering and increase student likelihood to persist in the profession, provides justification for investigating the use of the spaces to prepare undergraduate students to become engineers.

We found some results that provide warrant for further investigation such as, the comparatively lower level of trust in other students in makerspaces. There may be an array of reasons for the potential lack of trust such as not sharing equipment, tasks, leadership, or ideas. It may also be that some students may ignore or disregard the perspectives of other students. Regardless, the lack of trust may negatively influence the desire to learn and take risks to explore ideas in the spaces. Further, a difference in lack of trust was also found for gender, with females indicating a lower level of trust in other students than males. The lack of trust may have profound implications for belongingness and therefore persistence in preparation and persistence in the profession.

The multiple differences we found for gender are of importance, and reflect a need to be more attentive to the perspectives and needs of females in engineering preparation programs. We recognize that the means between males and females were consistently within the same regions 
on the scales indicating that there were not extreme differences. However, the fact that there were differences with females scoring consistently lower than males does raise concerns about issues of equity and inclusion. In future research we plan to explore the issues of belongingness of females in makerspaces in more depth to determine what they perceive are the barriers to being included and treated equitably.

We speculate that the nature of makerspaces and the assignments or projects that students work on in the spaces, are structured in ways that allow for numerous potential solutions. Thus, the flexibility of the spaces and the work within the spaces allow students to explore possibilities and foster student creativity and willingness to take risks in the spaces. The structures of the spaces are also likely to support students' willingness to work toward mastery of ideas, rather than being strictly performance focused in their learning goal orientations.

We were encouraged to find that there were students who considered their work in the spaces to be aligned with the focus of the $21^{\text {st }}$ century engineer goal of service to society. We speculate that the potential projects and uses of the spaces is aligned with finding solutions to meet societal needs. Thus, while the students may use the spaces for personal projects and exploring the use of equipment to make items for personal use, their course assignments are likely to have different foci aligned with the actual work of engineers.

\section{Limitations and Future Research}

The first limitation of our research is the lack of an ability to gain a deeper understanding of why students responded the way they did to the items on the survey. We did base our survey based on interviews and observations of students to determine the potential learning and related variables associated with working in makerspaces. Continuing to explore why students answered the way they did in relation to our survey items, is a potentially fruitful line of continued research on student learning in makerspaces.

The second limitation of our research is the lack of knowledge of the structure and management of the makerspaces at the institutions from which we invited the students to participate in our research. As we have found from our ongoing research, there is a wide range of configurations of how makerspaces are structured, managed, and used for instruction. Building on to the existing literature, we will continue to explore the relationship between student learning and the configuration of makerspaces [2], [29].

Similar to our second limitation, our third limitation is the lack of knowledge of what the students were actually doing in the spaces and why they make the choices that they do in the spaces. While we have found some similarities of what undergraduate engineering students are doing in makerspaces, we have also found differences. A very important line of research that is needed is: how are students interactions in the spaces related to what they are learning about in the spaces?

\section{Conclusions}


In an ongoing effort to empirically document what students are learning and experiencing in makerspaces, we conducted a large scale survey of undergraduate engineering majors at 28 universities with established program integrated makerspaces. We found positive trends in the students experiences and learning in the spaces, providing support for the importance of retaining and supporting the spaces in undergraduate engineering education programs. 


\section{References}

[1] S. Lanci, L. Nadelson, I. Villanueva, J. Bouwma-Gearhart, K. L. Youmans, and A. Lenz, "Developing a measure of engineering students' makerspace learning, perceptions, and interactions," in 2018 ASEE Annual Conference and Exposition, Salt Lake City, UT, USA, June 24-27, 2018, American Society for Engineering, 2018.

[2] K. Youmans, I. Villanueva, L. Nadelson, J. Bouwma-Gearheart, A. Lenz, and S. Lanci, "Makerspaces vs Engineering Shops: Initial Undergraduate Student Impressions," 2018 IEEE Frontiers in Education Conference (FIE), pp. 1-5. IEEE, 2018.

[3] T. Barrett, M. Pizzico, B. Levy, R. Nagel, J. Linsey, K. Talley, C. Forest, and W. Newstetter, "A review of university maker spaces," in $122^{\text {nd }}$ ASEE Annual Conference and Exposition, Seattle, WA, USA, June 14-17, 2015, American Society for Engineering, 2015.

[4] K. Youmans, I. Villanueva, L. Nadelson, and A. Lenz, "Makerspaces vs. engineering shops: initial undergraduate student perspectives," IEEE Frontiers in Education Conference, vol. 1570430903, 2018.

[5] K. Youmans, I. Villanueva, L. Nadelson, J. Bouwma-Gearhart, A. Lenz, and S. Lanci, "Engineering Students' Perceived Value of Campus Makerspaces For Future Career Preparation," International Symposium on Makerspaces, 2018.

[6] P. Taheri, P. Robbins, and S. Maalej, "Makerspaces in First-Year Engineering Education," Education Sciences, vol. 10, no. 1, 2020.

[7] P. Dickrell, and L. Virguez "Making the Makers: Building Hands-on Skills to Help Humanity Through First-Year Design," American Society for Engineering Education, Tampa Bay, FL, 2019.

[8] A. Wigner, M. Lande, and S. Jordan, "How can maker skills fit in with accreditation demands for undergraduate engineering programs?" American Society for Engineering Education, New Orleans, LA, 2016.

[9] E. Brubaker, V. Maturi, B. Karanian, S. Sheppard, and D. Beach, "Integrating Mind, Hand, and Heart: How Students Are Transformed by Hands-On Designing and Making," American Society for Engineering Education, Tampa Bay, FL, 2019.

[10] K. Sheridan, E. Halverson, B. Litts, L. Brahms, L. Jacobs-Priebe, and T. Owens, "Learning in the making: A comparative case study of three makerspaces," Harvard Educational Review, vol. 84, no. 4, p 505-531, 2014.

[11] ABET (2017). Criteria for accrediting engineering programs, 2018-2019. Retrieved from https://www.abet.org/accreditation/accreditation-criteria/criteria-for-accrediting-engineeringprograms-2018-2019/ 
[12] L. Nadelson, I. Villanueva, J. Bouwma-Gearhart, S. Lanci, K. Youmans, C. Lenhart, A. Van Winkle, "Knowledge in the Making: What Engineering Students are Learning in Makerspaces," American Society for Engineering Education, Tampa Bay, FL, 2019.

[13] V. Wilczynski, "Academic maker spaces and engineering design." American Society for Engineering Education, vol. 26, 2015.

[14] P. Galloway, "The 21st-century engineer: A proposal for engineering education reform," American Society of Civil Engineers, 2007.

[15] I. Villanueva, and L. Nadelson, "Are we preparing our students to become engineers of the future or the past?" The International journal of engineering education, vol. 33, no. 2, p 639-652, 2017.

[16] C. Dweck, "Motivational processes affecting learning," American Psychologist, vol. 41, no. 10, 1986.

[17], P. Pintrich, and D. Schunk, Motivation in education: Theory, Research, and Applications (2nd ed.). Upper Saddle River, NJ: Prentice Hall, 2002.

[18] C. Dweck, and E. Leggett, "A social-cognitive approach to motivation and personality," Psychological Review, vol. 95, no. 2, 1988.

[19] E. Linnenbrink, and P. Pintrich, "Achievement goal theory and affect: An asymmetrical bidirectional model," Educational Psychologist, vol. 37, no. 2, p. 69-78, 2002.

[20] A. Elliot, "Approach and avoidance motivation and achievement goals," Educational Psychologist, vol. 34, no. 3, p. 169-189, 1999.

[21] P. Pintrich, "An achievement goal theory perspective on issues in motivation terminology, theory, and research," Contemporary Educational Psychology, vol. 25, no. 1, p. 92-104, 2000.

[22] R. Ryan, and E. Deci, "Self-Determination Theory: Basic Psychological Needs in Motivation, Development, and Wellness," Guilford Publications, 2018.

[23] C. Brooks, and S.Young, "Are Choice-Making Opportunities Needed in the Classroom? Using Self-Determination Theory to Consider Student Motivation and Learner Empowerment," International Journal of Teaching and Learning in Higher Education, vol. 23, no. 1, p. 48-59, 2011.

[24] M. Evans, and A. Boucher, "Optimizing the power of choice: Supporting student autonomy to foster motivation and engagement in learning," Mind, Brain, and Education, vol. 9, no. 2, p. 87-91, 2015.

[25] S. Lee, D. Bar-El, K. Martin, and M. Worsley, "Facilitation in informal makerspaces," International Society of the Learning Sciences, Inc.[ISLS], 2018. 
[26] J. Reeve, E. Bolt, and Y. Cai, "Autonomy-supportive teachers: How they teach and motivate students," Journal of educational psychology, vol. 91, no. 3, 1999.

[27] C. Dweck, "What having a "growth mindset" actually means," Harvard Business Review, vol. 13, p. 213-226, 2016.

[28] C. Dweck, "Carol Dweck revisits the growth mindset," Education Week, vol. 35, no. 5, p. 20-24, 2015.

[29] M. Hynes, and W. Hynes, "If you build it, will they come? Student preferences for Makerspace environments in higher education," International Journal of Technology and Design Education, vol. 28, no. 3, p. 867-883, 2018. 